\title{
Personal Experience Narrative Structure in “Al-ikhlas” Hadith
}

\author{
Nahla Nadeem ${ }^{1}$ \\ ${ }^{1}$ Faculty of science and arts, King AbdulAziz University, Rabigh, Saudi Arabia \\ Correspondence: Nahla Nadeem, King AbdulAziz University, Rabigh branch, Saudi Arabia.
}

Received: October 2, 2021

Accepted: November 10, 2021

Online Published: November 22, 2021

doi:10.5539/ells.v12n1p12

URL: https://doi.org/10.5539/ells.v12n1p12

\begin{abstract}
Using personal experience narrative in different forms of teaching and preaching is so common that it is unsurprising that it has been the object of scholarly attention and research. The present study aims to apply Labov's model of narrative structure to the personal experience narratives (PENs) in the sincerity hadith. Sincerity_-"Alikhlas"-is defined as being deeply devoted to Allah by heart and actions. According to Islamic teachings, a sincere person not only has a deep fear of Allah, but his intentions in all actions are mainly to please Him. Drawing on Labov's work on PEN structures (1972; initially Labov \& Waletzky, 1967, 1981, 1997), the study attempts to answer two key questions: a) whether or not the Labovian model applies to the PENs in the hadith and b) how effective the model is in establishing the link between what was said (i.e., the stories told), how the narratives were structured and the Islamic concept the hadith was meant to teach. The analysis shows that though the hadith belongs to a different language with assumedly different socio-linguistic narrative practices, the Labovian model works as an effective tool of analysis as it sheds light on how the overlapping layers of the narratives were structured to define the Islamic concept of "sincerity".
\end{abstract}

Keywords: personal experience narrative, narrative analysis, sincerity, hadith, evaluative language, narrative structure.

\section{Introduction}

Personal experience narrative (PEN) is a pervasive form of discourse through which we construct, interpret, and share our experiences. Richardson (1990, p. 118) defined narrative as the "primary way through which humans organize their experiences into temporally meaningful episodes". She further wrote that "narrative is both a mode of reasoning and a mode of representation". People can apprehend the world narratively and people can tell about the world narratively (see Richardson, 1990, p. 118). Previous research on the rhetorical power of personal experience narrative provides evidence that it is one of the most powerful rhetorical tools that public speakers often use to persuade and enlighten their audience (see Bandura, 2004; Gesser-Edelsburg \& Singhal, 2013; Green, 2006; Moyer-Gusé, 2008; Nadeem, 2019 \& 2020; Schreiner et al., 2018; Shen et al., 2015; Slater, 2002; \& Slater \& Rouner, 2002).

In sociolinguistic studies, personal experience narrative has been one of the major areas of research. By drawing on cultural knowledge and expectations, storytellers manage to construct story topics, themes, and points (see Bamberg, 1997a, 1997b, 2004, 2005, 2006, 2016; De Fina \& Georgakopoulou, 2012; Polanyi, 1982 \& 1985). They make their past experiences relevant to, a particular "here" and "now," a particular audience, and a particular set of interactional concerns and interpersonal issues" (Moore, 2006). Researchers have explored various questions ranging from the formal structure and function of narrative (Bamberg, 1997a, 1997b, 2004, 2005, 2006, 2016; Bamberg \& Damrad-Frye, 1991; Bamberg \& Georgakopoulou, 2008; Gonzalez, 2009; Hyv゙arinen et al., 2010; Herman, 2009; Labov \& Waletzky, 1967, 1997; Labov, 1981; Labov, 1972, 2006; Ozyıldırım, 2009; Pilkington, 2017; Shiro, 2003), to the use of narrative in the presentation of self and identity (Georgakopoulou, 2016; Nadeem, 2015, 2020; Ochs \& Capps, 1996, 2001; Schiffrin, 1996) to how narrative reflects the social context in which it was created (Moore, 2006; Schiffrin, 2009; Tannen, 1980, 1982, 1989, 2008; Tsitsipis, 1988; Watson, 1973).

Sociolinguistic research has primarily focused on oral narratives that recount personal experiences. According to Ochs and Capps (2001), oral narratives are particularly universal modes of discourse documented in every known culture as (a) they verbalize human experience in a way that moral meaning of events and people can be drawn; and (b) they have as Labov (1972) points out a fairly regular structure that can be easily accessed and 
processed by the audience. An important discourse process underlying narrative structure is what Labov (1972) called verbalization: the way storytellers "symbolize, transform, and displace a stretch of experience from their past - what they have done, and what has happened to them - into linguistically represented episodes, events, processes, and states". Prior research also tells us that this process of transforming personal experience into verbal performance is interwoven with the way stories are socially and culturally situated (Schiffrin, 1996, p. 168). Stories often reflect common social beliefs about roles and states; value systems of what constitutes moral accepted or unaccepted behavior in a given social context. This is the repertoire preachers draw upon in their ethical teaching; and therefore, either reinforce existing moral stances or reshape human experience through narrative. A narrative mode of communication easily captures the audience's attention and gets them immersed into the story world, which allows them to establish common views and attitudes through sharing the interpretation of events.

So common is using narrative in different forms of teaching and preaching that it is unsurprising that narrative form, meaning, and use have been the object of extensive scholarly research. Stories and narratives are extensively used in the Quran, the Bible and Prophet Muhammed's hadiths as a teaching and preaching tool (see Carney, 1973, 1983; Speight, 2000). Narratives give preachers a tool to reframe the human experience in order to make an ethical/moral stance. Through narrative, preachers can provide concrete-real life - examples of topics, themes and moral stances they wish people to consider or adopt. Such a view of narrative is elaborated by Ochs and Capps (2001, p. 225), who observe how "narrative activity draws interlocuters into probing moral dimensions of human experience". As Johnstone (2001, p. 635) states "the essence of humanness, long characterized as the tendency to make sense of the world through rationality, has come increasingly to be described as the tendency to tell stories, to make sense of the world through narrative". The ability of narrative to verbalize and place human experience as discourse provides a resource for theological and ethical teaching.

Personal experience narratives are particularly used as preparation and support for introducing a theme or concept of theology as in the case of the sincerity hadith. Preachers can use oral narrative to explore moral stances. In the paper, I argue that Labov's model captures some of the basic elements of PEN and can be used as an effective tool of analysis of PENs not just in elicited English oral discourse but other genres in non-Western languages. The model was widely applied without modification to different narrative data and found useful in capturing and analyzing the basic structure of oral narrative discourse. Yet, there is still a need for further research to investigate the narrative structures in a religious text such as hadith and the present study aims to fill this gap. It is also noteworthy that the ikhlas hadith is classified in Riyad As-Salihin —one of the most widely known and read books of hadith all over the world - under the theme of sincerity. The selections of compiled hadiths in Riyad As-Salihin are known to be authentic and this one particularly comes in the form of an extended narrative and therefore fits the purpose of the study.

In what follows, section 1 provides a brief summary of the hadith and the three PENs, section 2 tackles Labov and Wetzley's model of personal experience narrative structure (1967) and Labov (1972). Part 3 applies Labov's model on the three PENs in hadith. The analysis also explores how the shift from referential to evaluative language works as a tool to structure, assign meaning and develop moral stances in the hadith. Part 4 includes the discussion of the analysis and the significance of the model in illustrating how the PENs were used to define sincerity as a key Islamic concept.

\subsection{A Brief Summary of the Hadith}

In the hadith, the Prophet told his companions the story of three men who were travelling and took refuge in a cave. When they got in, a rock fell and blocked the entrance. When they felt their end was inevitable, one of them told them that the only thing that would save them is to call upon God invoking the good actions they had done. So, each told a PEN that he deemed to be sincerely done for the sake of God. The first man told a story of his kindness to his parents, the second man told a story of how his fear of God stopped him from committing an act of adultery, and the third narrated a story of how he invested one of his workers' dues until they became a fortune then gave them all to him when he came asking for his previous wages. The three PENs were thematically connected as they all narrated past events that were done only for the sake of God and therefore were deemed to be "sincere" and redeeming". After each personal narrative, the rock moved slightly but not enough to get them all out until at the end the rock was miraculously removed and they were saved. The point behind the hadith - as hadith scholars pointed out — was that these acts of sincerity and perfection "ihsan" are not just life-transforming experiences but are life-saving at times of hardship and trial (Rahman, 1983). The hadith invites Muslims to examine their inner motives in whatever they are doing and at times of hardship and trials, they can call upon God invoking these sincere acts as life-saving experiences. 


\section{Literature Review: Labov's Narrative Structure Theory (1972)}

One of the most influential models that tackled the formal structure and function of personal experience narrative, is presented by Labov and Waletzky (1967) and Labov (1972). Labov's seminal work on PEN structure began in the context of his study of the varieties of English spoken in New York City. In order to elicit unselfconscious, 'vernacular' speech, Labov had people tell stories about themselves, often stories about dangerous or embarrassing experiences. Labov (1972, p. 360) defines narrative as one method of recapitulating past experience by matching a verbal sequence of clauses to the sequence of events which actually occurred. He (1972) defines narrative clauses as the basic unit of analysis, around which everything else is based. According to Labov (1972, pp. 360-363), a 'minimal narrative' contains at least two narrative clauses; those with referential functions are characteristically ordered in temporal sequence and are meant to ground the story in its contextual world. If the sequence order is reversed, it will result in a change in the original semantic interpretation. For example, "I punched this boy/and he punched me" implies a different sequence of events than "this boy punched me/and I punched him", and thus, has a different meaning" (Ozyıldırım, 2009, p. 1211). Narrative clauses with evaluative function, however, describe the storyteller's purpose in telling the story as they provide clues as to how to understand the events.

According to Labov (1972) and Labov and Waletzky (1967), PENs as discourse units have a fairly constant inherent structure. Labov and Waletzky propose a 'formal' approach to PEN which describes the invariable semantic deep structure of PEN, correlating surface differences with the 'social characteristics' of narrators (as cited in Ozyıldırım, 2009, p. 1211). A 'fully-formed' narrative may include clauses or sets of clauses with the following functions, occurring more or less in this order:
1) abstract
2) orientation
3) complicating action
4) evaluation
5) result or resolution
6) coda.

The abstract consists of one or two clauses at the beginning of a narrative and gives an overview of the whole story. It answers the questions 'What is the narrative about?'

The orientation provides information about the time, place, characters, and the activity in which they are engaged. It answers the question, 'Who is the person or persons involved in the narrative?', 'What are the events?' and 'When/where did the events take place?' This subcategory often includes clauses with referential function as they provide all the contextual clues that precede the main story.

The complicating action (or the high point of the story) includes the main events and is considered obligatory for the formation of a narrative. It answers the question 'Then what happened?' and often contains the climax or even more than one complicating action.

Evaluation provides the morale of the story and the reason why the narrative is told in a particular way, and what the narrator's aim in doing so. It shows the emotional side of the narrative as it provides additional information about how the narrator feels about the events, he/she experienced and why the story is worth telling.

The result or resolution informs the audience about how the complicating action is resolved. It answers the question 'What finally happened? This section provides a closure to the events and a release of the accumulative tension.

Coda clauses, which are located at the end of the narrative, often bridge the gap between the time of the narrative and the present moment. It also allows the story teller to provide his/her own observations about the story as a whole.

While not all narratives have all the six components, the model is an excellent analytical and descriptive tool that is based on actual data of oral narrative discourse (see Labov, 1972, pp. 365-370). Labov's analysis of evaluative language what he called "high point analysis" is an important contribution of the model. Labov's highpoint analysis often comes in critical moments of the narrative in which the resolution of the problem is usually highlighted by evaluation from the narrator. So far, the framework developed for oral narratives of personal experience proved to be useful in analyzing the macrostructure of stories in a wide variety of narrative types; e.g., everyday conversation narrative, interviews and oral memoirs. However, it hasn't been applied to oral narratives 
in Arabic religious discourse and particularly in hadith. There still needs to be more investigation of PEN in the conext of preaching in general because when PENs are employed as a preaching tool as in the case of the present hadith, the framework and the subcategories might operate differently; particularly, the distinction between narrative and evaluative language.

\subsection{Labov et al.'s Analysis of Narrative and Evaluative Language in PEN}

As a discourse unit, PEN is a linguistic technique of reporting past events to an audience or interlocutors. In PENs, narrators often select the most important moments of their lives, moments that lead to key transformations and insight. According to Labov (1972), the narrative basically consists of two types of clauses: narrative or evaluative. Narrative clauses provide information about the characters, settings or events in the story, serving a referential function. On the other hand, evaluative clauses suspend the temporal sequence of events, focusing on the evaluation of events. Labov and Waletsky's PEN model $(1967,1997)$ and subsequent work, including Labov (1997), provided a detailed analysis of naturally occurring personal narrative to illustrate how different kinds of narrative clauses can variously perform referential and/or evaluative functions. They observe that the underlying referential form of a narrative is found in its primary sequence: the sequence of narrative clauses which are temporally ordered according to an a-then-b relation (Labov \& Waletsky, 1967, 1997, pp. 25-26). Typically, there are at least two clauses separated by a temporal juncture and a reversal of their order results in a change in the listener's interpretation of the order of the events. Narrative clauses with referential function might be presented in other types of clauses, which can have a more complex relation than the temporal sequence of the narrative, e.g., "coordinate clauses (clauses which may be freely interchanged with adjacent clauses without changing the temporal sequence); restricted clauses (clauses which have restricted temporal placement in the narrative; that is, they can be moved, but not throughout the whole narrative); and free clauses (clauses which can be freely placed throughout the narrative)". Labov and Waletsky state that evaluation can occur in any of these types of clauses, but is characteristically found in coordinate, restricted or free clauses - as these types of clauses can be used to suspend the action whilst narrator interpretation is offered (as cited in Moore, 2006, p. 618). Given that evaluation is frequently used as a form of a frame; a lens through which the narrated events are to be perceived. Labov and Waletsky's $(1967,1997)$ model offers an analytic tool to identify how narrative allows preachers to take moral stances and engage listeners in the process of evaluating theirs. Consequently, evaluative language is particularly significant in ethical teaching.

\subsection{Evaluative Language in Personal Experience Narrative}

Evaluation in narrative provides interpretive information which shows the meaning of the narrative events from the narrator's perspective. Evaluative language indicates the point of the narrative, its raison d'etre: what the narrator wishes to convey and why it was told (Labove, 1972, p. 366). Very often, evaluative expressions help to relate the events to the narrator's value system. It is any linguistic expression referring to emotions, attitudes, beliefs, and affect, i.e., non-factual, perspective-building elements contributing to the expressive function of the story (Labov \& Waletzky, 1967; Labov, 1972). According to Labov, there are many devices through which the point of a narrative can be conveyed. "Evaluation may appear in free clauses that comment on the story from outside: "And it was the strangest feeling"; or in clauses that attribute evaluative commentary to characters in the story: "I just closed my eyes". Or evaluation can also be embedded in the narrative, in the form of extra detail about characters: "I was shaking like a leaf", suspension of the action via paraphrase or repetition; 'intensifiers' such as gesture or quantifiers: "I knocked him all out in the street"; elements that compare what happened with what did not or could have happened or might happen; 'correlatives' that tell what was occurring simultaneously; and 'explicatives' that are appended to narrative or evaluative clauses" (as cited in Ozyıldırım, 2009 , p. 1212). One of the evaluation techniques as Tannen $(1986,1989)$ points out is how and why storytellers "construct" dialogue for characters in their stories, in which these characters reveal first hand how they feel about the events.

Labov presented a very detailed analysis of syntactic devices within the clause which serve this function as well as other mechanisms of evaluation. The Labovian model offers a rigorous analytical tool to describe PENs; however, the narrative structure described was typically western. Following Labov and Waletsky's framework, a growing body of research on the use of evaluative devices in narratives has been carried out (see Bamberg \& Damrad-Frye, 1991; Brookes et al., 2018; Eaton et al., 1999; Ozyıldırım, 2009; Peterson \& McCabe, 1983; Shiro, 2003). Although there are studies of oral narrative structure in languages other than English like Spanish (Shiro, 2003), Turkish (Ozyıldırım, 2009), Swedish (Brumark, 2003), and Hebrew (Berman \& Slobin, 1994), the model has not been applied to oral narrative of personal experience particularly those used in Islamic hadith.

In Islamic tradition, the hadith is classified under the theme of "sincerity" and is expected not just to define it but 
to give real-life examples of it through the PENs told. Structurally, the hadith is a composite form of narrative within which at least two layers of narrative can be recognized: the Prophet's narrative and the PENs told by the three characters. The Prophet started off the narrative addressing his companions and introducing the three men and then the three personal narratives were given from the three characters' vantage point using direct speech. The manipulation of PEN as a preaching technique makes the hadith an interesting data for narrative inquiry research and sociolinguistics. The analysis only focused on the English translation of the hadith and attempts to answer the following questions:

RQ1: Whether or not the Labovian model of personal experience narrative is realized in the hadith PENs? In other words, how does the model help in explaining the relationship between what is said - "the narrative proper", and how and why it was said "the moral behind it"?

RQ2: How is the evaluative language employed in hadith and what are the implications for narrative inquiry?

\section{The Analysis}

\subsection{The Prophet's Narrative of the Three Men's PENs}

Narrated by Ibn 'Umar, The Prophet said:

Three men of the past were travelling and took refuge for the night in a cave. They entered it and a rock fell down the mountain and blocked the entrance. They said, 'The only thing that will rescue us from this rock is to call on Allah invoking good actions we have done! (see http://islamicshahada.blogspot.com/2007/02/story-of-three-men.html)
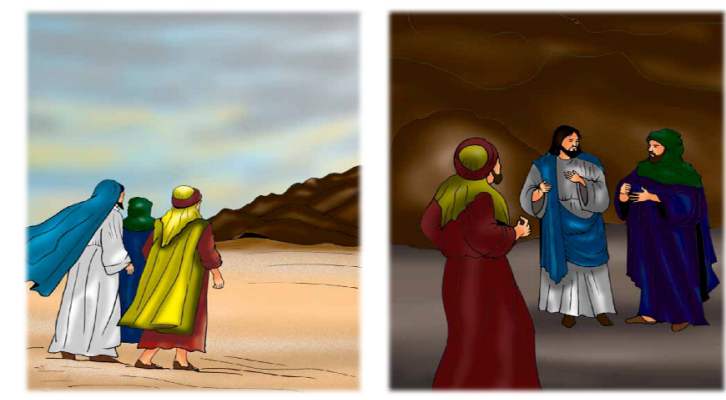

Figure 1. The three men got in the cave and the rock blocked the entrance

Though short and condensed, the prophet's narrative realized all the criteria of Labov's model. It answered all the basic questions of "who", "when", "did what" and "then what". The complicating action was realized in the two clauses "a rock fell down the mountain and blocked the entrance." The resolution was represented in "They said, "The only thing that will rescue us from this rock is to call on Allah invoking good actions we have done!". This resolution had multiple functions: a) It gave a sense of closure to the Prophet's narrative; b) it set the scene for the following PENs; c) it worked as an interpretive frame for the following PENs and d) it marked the shift in setting from the "where and now" of the first narrative to the past recapitulation of the PENs which happened elsewhere in the past. The shift to direct speech in the PENs also helped to shift the setting for the companions as a live audience. In the Arabic version, the whole narrative is connected as one structural unit via the recurring use of "fa" preposition for sequencing in Arabic - meaning "and then"- unlike the English text where the narrative flow was interrupted by full stops. The narrative sequence of the events has a referential function explaining the who, where, when of the events till the last evaluative statement, "they said: the only thing ... done"-which functioned as a closure to the Prophet's narrative. It is evaluative in the sense that it provided a frame for interpreting the following PENs - which were not to be merely seen as simple accounts of what happened to those men in the past but as accounts of moral acts that they did in their lives for the sake of God prior to the time of hardship and trial.

\subsection{The Three Men's Personal Experience Narratives}

The PENs, however, marked the beginning of the second layer of narrative in hadith-which was subdivided into three distinct yet related PENs. The setting of the PENs was the cave; yet, the episode itself took place prior to the act of narration. The three PENs had clear beginnings, climactic middle and repeated endings. They all shared the common entrée and conclusion "O God I". In all narratives, the recurring call upon God was not just 
the unifying element but the embodiment of the "sincerity" theme. The Prophet interrupted the three men's narration at two key points: at the beginning of each episode through the use of indirect speech saying, "The first man said", "the other said" and "the third said"; and at the end through the closure statement, "The rock moved a little further but they still could not get out" until the final resolution at the end of hadith when he said, "The rock moved away and they walked out"'. According to Labov's model, the Prophet's introduction of each episode functioned as an abstract and orientation while the three PENs functioned as continued CAs for the first layer. For the companions as live audience, the recurring climactic question at the end of every PEN was "will the rock move?" and "will they be saved?" With the narration of each PEN, the structure got more complicated in terms of setting and viewpoint and also more interwoven in terms of the overlap between narrative clauses with referential function and those with evaluative function.

\subsubsection{The First Man's PEN}

The Prophet said:

One of them said, "O Allah, my parents are both old and it is my habit never to give milk in the evening either to my family or friends before giving it to them first. One day I went a long way in search of something and did not reach them until they had already gone to bed. I milked their evening drink but found them asleep. I did not want to wake them nor to give my family or friends their evening drink before they had had theirs, so I remained with the cup in my hand waiting for them to wake up until dawn came. The children were at my feet, crying because of hunger. Then they woke up and drank their drink. O Allah, if I did that out of the desire for Your Face, then rescue us from the situation we are in regarding this rock." It opened up a little but they still could not get out. (see http://islamicshahada.blogspot.com/2007/02/story-of-three-men.html)
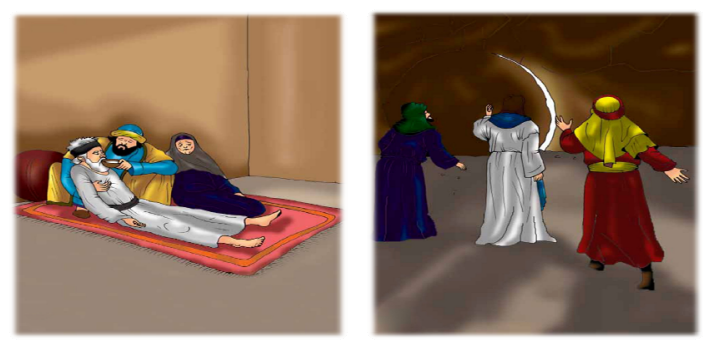

Figure 2. The first man with his parents and the rock removed a little

The first PEN fitted Labov's six category model as follows:

The Prophet's orientation: "One of them said":

The first narrator's orientation: "O Allah" my parents are both old

Evaluation: And it is my habit never to give milk in the evening either to my family or friends before giving it to them first."

Complication action: "One day I went a long way in search of something and did not reach them until they had already gone to bed. I milked their evening drink but found them asleep.

Evaluation: I did not want to wake them nor to give my family or friends their evening drink before they had had theirs,

High point: So I remained (with the cup in my hand) waiting for them to wake up until dawn came.

Evaluation: The children were at my feet, crying because of hunger.

Resolution: "Then they woke up and drank their drink (milk)"

Evaluation and coda: "O Allah, if I did that out of the desire for Your Face (out of fear of Allah), then rescue us from the situation we are in regarding this rock."

The Prophet's closure/evaluation \& coda statement: "It opened up a little but they still could not get out."

Providing extra care to one's old parents is a common theme in Islamic teachings. In the narrative, the man had two old parents and he not only provided extra care for them but made a saintly vow, "never to give food to 
anybody before he feeds his parents first". One day he came late to find them both asleep. There were many courses of action that could be reasonably taken without breaking his vow and still counted as moral acts in his situation; e.g., he could wake them up or keep the food for them until they woke up the next day. The man however chose to stick to his saintly vow with God and stayed all night by their side until they woke up and gave them their food. The moral obligation here was only his commitment to his vow with God which was subtly revealed in the repetition of "O Allah" twice in the narrative - once in the beginning and at the end when the rock slightly opened. Here, narrative and evaluative clauses were observed to be overlapping. In many instances, the temporal sequence is suspended as the narrator gave an evaluative remark, e.g., And it is my habit" and "the children were at my feet, crying because of hunger". Other evaluative elements were provided lexically and on phrasal level - e.g., by the lexical choice of the verb "لبثت in Arabic to describe the long wait for the parents to wake up or the act of carrying the cup "I waited with the cup in my hand" or using a temporal detail to show that he waited all night - e.g., "until dawn came".

\subsubsection{The Second Man's PEN}

The Prophet said:

The second said, "O Allah! A cousin of mine was the person I loved more than any other. (Another variant has, "I used to love one of my uncle's daughters with the most intense love it is possible for a man to have for a woman.") I tried to seduce her and she refused me until, one year when she was in dire need, she came to me and I gave her a hundred and twenty dinars provided that she would let me do what I wanted with her. She did that but when I was about to have my way with her, (One variant has, "when I was between her legs.") she said, 'Fear Allah and do not break the seal without having the right to do so.' Then I left her alone in spite of the fact that she was, of all people, the one I loved the most and also left her with the gold I had given her. O Allah, if I did that out of the desire for Your Face, then rescue us from our situation!" The rock moved a little further but they still could not get out. (see http://islamicshahada.blogspot.com/2007/02/story-of-three-men.html)
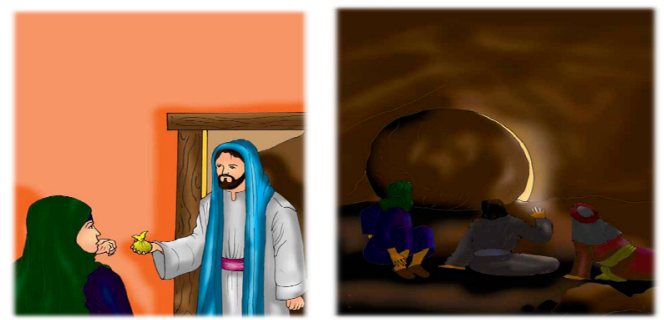

Figure 3. The second man giving the money to his cousin and the rock opened a little more

The second PEN seemed to match all the categories in Labov's model (1972):

The Prophet's orientation: "The second said"

The second narrator's orientation: ““'O Allah", a cousin of mine ..." I tried to seduce her and she refused me Evaluation: (She) was the person I loved more than any other. (Another variant has, "I used to love one of my uncle's daughters with the most intense love it is possible for a man to have for a woman."

Complication action: Until, one year when she was in dire need, she came to me and I gave her a hundred and twenty dinars

Evaluation: Provided that she would let me do what I wanted with her.

High point: She did that but when I was about to have my way with her, she said

Evaluation: (One variant has, "when I was between her legs."), 'Fear Allah and do not break the seal without having the right to do so."

Resolution: "Then I left her alone... and also left her with the gold I had given her."

Evaluation: In spite of the fact that she was, of all people, the one I loved the most

Evaluation and coda: "O Allah, if I did that out of the desire for Your Face... situation!"

Prophet's closure/evaluation and coda statement: It opened up a little but they still could not get out." 
The second PEN is another example of the second man's sincerity-i.e., 'refraining from wrong doing and doing an act of goodness for the sake of Allah'. Here, the man was far from being a "hero"- - using a cousin's dire need to satisfy his sexual desire was totally unethical. In his own words, he loved his cousin more than anybody else in the world and it seemed that he always had an internal desire for her. The reason why he never thought of marrying her - as she suggested at the high point of the story - was unknown. When the opportunity came to act upon the desire, she reminded him of Allah saying "fear Allah and do not break the (virginity) seal without having the right to do so" and he backed off immediately. The heroic act here was one of self-restraint due to sincerity. The little significant details he added; e.g., "He backed off while he was literally between her legs"; "in spite of the fact that she was the one he loved most" and finally, "Giving her the money she needed" made the act heroic and sincere. The narrative clauses all tackled what was going on externally with the woman while the evaluative remarks mainly pointed to the internal conflict the man had until it culminated into the full withdrawal of the sinful act. Finally, the Prophet provided the final closure remark that linked the two layers of narrative together as well as identified the whole episode as an act of sincerity and therefore "redeeming" for the three men.

\subsubsection{The Third Man's PEN}

\section{The Prophet said:}

The third said, "O Allah, I employed some workers and gave all of them their wages except for one man who went off without taking what he was owed. I invested his wage until it multiplied in value. After a time, he came to me and said, "Abdullah, pay me my wage!' I said, 'All the camels, cattle, sheep and slaves that you see here have come from your wage.' He said, “Abdullah, do not make fun of me?' I said, 'I am not making fun of you.' He took them all and drove them off, not leaving anything. O Allah, if I did that out of the desire for Your Face, then rescue us from the situation we are in!" (see http://islamicshahada.blogspot.com/2007/02/story-of-three-men.html)
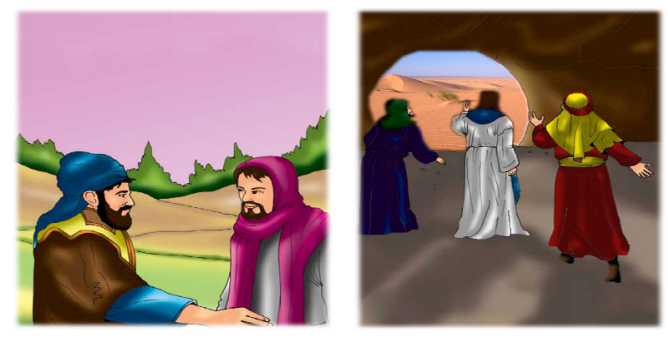

Figure 4. The third man giving the worker's dues and the rock was completely removed and they were saved

The third PEN also matched the Labovian model:

The Prophet's orientation: "The third man said"

The third narrator's orientation: "O Allah", I employed some workers and gave all of them their wages except for one man who went off without taking what he was owed."

Complication action and high point: "I invested his wage (sheep and camels). After a time, he came to me and said, “Abdullah, pay me my wage!' I said, 'All the camels, cattle, sheep and slaves that you see here have come from your wage.

Evaluation: I invested his wage until it multiplied in value

High point: He said, “Abdullah, do not make fun of me?' I said, 'I am not making fun of you.”

Resolution: "He took them all and drove them off,

Evaluation: Not leaving anything.

Evaluation and coda: "O Allah, if I did that out of the desire for Your Face, then rescue us from our situation!"

Prophet's closure/evaluation and coda statement: "The rock moved away and they walked out."

The third man's episode was an excellent example of sincerity and perfection "ihsan"- "giving beyond one's duty". It could have been ethical enough if the man gave his employee the due wages without the added value of investment. Ethically, the third man was under no obligation to give him the return on his wages' investment or to do the investment in the first place. Yet, the amazing part came in the final little detail "he took them all and 
drove them (all the sheep and camels) off, not leaving anything." The worker himself realized that this was too good to be true in "Abdullah (slave of God), do not make fun of me?" It explained why he hastened to take everything and walked away lest the man should change his mind about this huge act of generosity.

As shown above, the three PENs were thematically linked via the repeated use of "Allah" in the orientation and closure of each episode. They also exhibited the same structural pattern since each episode represented the six categories of Labov's model almost in the same order. As shown in the analysis, the prophet's introduction and conclusion of the PENs helped to link them thematically and also provided the framework for the PENs interpretation. At the end of each account, there was a suspension point and a question of "will it be redeeming for them all?" until they were finally saved at the end of the hadith.

\section{Discussion and Conclusion}

The analysis showed that the PENs in hadith exhibited all of Labov's six categories. However, due to the overlapping layers of narrative, each layer represented a different world with different characters and settings:

Layer 1: The Prophet was addressing the companions in supposedly real time

Layer 2: The three men were telling their personal experience narratives in the cave in their attempt to be saved

Layer 3: The PENs' past time when the narrated events took place

Therefore, abstract and coda categories were observed to operate differently on each level. For example, the abstract was given only once in the Prophet's narrative while the three PENs exhibited only orientation items in the beginning of each episode. The coda categories also occurred at the end of each PEN not to get the listener back to the present time but to mark the shift in the time frame and setting across the different narrative layers.

The analysis also gave empirical evidence that though there was evidence of the presence of the pattern of referential and/or evaluative clauses, yet, they often overlapped in the hadith. Narrative elements were often mixed with evaluative elements since the narratives themselves served as a framework for the evaluation. This made the distinction between clauses with referential function and those with evaluative function quite problematic. Evaluative expressions were not necessarily represented on a clausal level, but in many cases were reflected in the addition of meaningful details that were added to the referential narration itself either in the choice of lexical items or adding "phrases" to give specific evaluative details. For example, using the Arabic verb "فلقب" / "then I waited" (literally for some time) in the first episode as a narrative verb both indicated the temporal sequence of events and added an evaluative detail since the verb itself has meaning connotations of long duration and persistence. Key verbs especially in the complicating action usually carried evaluative meaning that made the separation quite difficult.

The analysis confirmed Johnstone's (2001) critique of the model. Johnstone (2001, p, 638) stated that Labov's model highly influenced later work in narrative analysis in several ways as it contextualized the study of the macrostructure of personal experience narrative connecting form to function. However, it can be argued that Labov's (1972) distinction between narrative clauses, representing the referential function of the narrative, and evaluative clauses, reflecting the expressive narrative function is quite problematic. Evaluative devices are often scattered all over the narrative and are sometimes inseparable from the narrative clauses as they form a variety of patterns fulfilling a number of functions in narrative discourse. She added that the categorization requires very detailed syntactic analysis, which is very difficult to apply to large-scale studies of narrative discourse.

The analysis, therefore, calls for a re-evaluation of the Labovian model of PEN in different genres and languages since not only does narration and evaluation seem to overlap but categories such as a complicating action and resolution often do due to the overlapping narrative structure in the hadith. Evaluative language often extends through the whole narrative and takes many forms: the selection of what to narrate; a lexical item with connotations that add an evaluative detail; or a parenthetical phrase.

Finally, by investigating the relationship between oral narrative and moral teaching, we illuminate how oral narratives can become stages for performing moral selves and for contemplating alternative/possible moral selves. When oral narratives are told by a preacher, they carry different purposes than narratives told among friends. Labov's (1972) notion of high point analysis through the narrator's evaluation is particularly important in the sense that it sheds light on this process of "assigning ethical meaning to human experience". Prophet's evaluative language and the "high point analysis" are key to understanding the main point behind the narrative.

As shown in the analysis, the PENs and the narrative as a whole are actually advocating a "sincerity" approach to ethics. It projects an image of a "sincere" Muslim and describes real-life actions that are aligned with this image. If sincerity becomes the motive behind human action, then and only then such heroic acts are possible in 
everyday life experiences. Thus, the PENs in the hadith invite Muslims to examine their inner motives in doing what they are doing as the hadith invariably couples moral action with sincerity as the criterion of acceptance and hence salvation in this life and hereafter.

\section{References}

Bamberg, M. (1997a). Positioning between structure and performance. Journal of Narrative and Life History, 7 , 335-342. https://doi.org/10.1075/jnlh.7.42pos

Bamberg, M. (1997b). Emotion Talk(s). The Role of perspective in the construction of emotions. In S. Niemeier \& R. Dirven (Eds.), The Language of Emotions (pp. 209-225). Amsterdam, The Netherlands: John Benjamins. https://doi.org/10.1075/z.85.15bam

Bamberg, M. (2000). Language and Communication: What Develops?-Determining the Role of Language Practices for a Theory of Development. In B. Nancy, U. Ina \& W. Jim (Eds.), Communication: An Arena of Development (pp. 55-77). Stamford, CT: Ablex/JAJ.

Bamberg, M. (2004). We are Young, Responsible and Male: Form and Function of "Slut-Bashing" in the Identity Constructions in 15-year-old Males. Human Development, 47, 331-353. https://doi.org/10.1159/000081036

Bamberg, M. (2005). Narrative Discourse and Identities. https://doi.org/10.1515/9783110201840.213

Bamberg, M. (2012). Narrative analysis. In H. Cooper, P. M. Camic, D. L. Long, A. T. Panter, D. Rindskopf \& K. Sher (Eds.), APA Handbook of Research Methods in Psychology (Vol. 2, pp. 85-102). Washington, DC: American Psychological Association. https://doi.org/10.1037/13620-006

Bamberg, M. (2016). Language, interaction, and culture. In H. Miller (Ed.), The SAGE Encyclopedia of Theory in Psychology (pp. 497-470). London, Delhi, New York: Sage Publications.

Bamberg, M., \& Damrad-Frye, R. (1991). On the ability to provide evaluative comments: Further Explorations of Children's Narrative Competencies. Journal of Child Language, 18, 689-710. https://doi.org/10.1017/S0305000900011314

Bamberg, M., \& Georgakopoulou, A. (2008). Small stories as a new perspective in narrative and identity analysis. Text \& Talk, 28(3), 377-396. https://doi.org/10.1515/TEXT.2008.018

Bandura, A. (2004). Social cognitive theory for personal and social change by entertainment-education media. In M. J. Cody, A. Singhal, E. M. Rogers \& M. Sabido (Eds.), Entertainment-Education and Social Change (pp. 75-95). Mahwah, NJ: Lawrence Erlbaum Associates.

Berman, R., \& Slobin, D. (1994). Relating Events in Narrative: A Cross-linguistic Developmental Study. Hillsdale, NJ: L. Erlbaum Associates.

Brookes, G., McEnery, T., McGlashan, M., Smith, G., \& Wilkinson, M. (2021). Narrative evaluation in patient feedback: A study of online comments about UK healthcare services. Narrative Inquiry. https://doi.org/10.1075/ni.20098.bro

Carney, F. (1973). Accountability in Christian morality. The Journal of Religion, 53(3), 309-329. https://doi.org/10.1086/486349

Carney, F. (1983). Some Aspects of Islamic Ethics. The Journal of Religion, 63(2), 159-174. https://doi.org/10.1086/487011

De Fina, A., \& Georgakopoulou, A. (2012). Analyzing Narrative: Discourse and Sociolinguistic Perspectives. New York: Cambridge University Press. https://doi.org/10.1017/CBO9781139051255

Eaton, J., Collis, G., \& Lewis, V. (1999). Evaluative explanations in children's narratives of a video sequence without dialogue. Journal of Child Language, 26, 699-720. https://doi.org/10.1017/S0305000999003967

Georgakopoulou, A. (2016). From narrating the self to posting self(ies): A Small Stories Approach to Selfies. Open Linguistics, 2, 300-317. https://doi.org/10.1515/opli-2016-0014

Gesser-Edelsburg, A., \& Singhal, A. (2013). Enhancing the persuasive influence of entertainment-education events: Rhetorical and aesthetic strategies for constructing narratives. Critical Arts, 27(1), 56-74. https://doi.org/10.1080/02560046.2013.766973

Gonza'lez, M. (2009). Narrative clause organization of Catalan and English storytelling. Journal of Pragmatics, 41, 540-563. https://doi.org/10.1016/j.pragma.2008.06.013

Green, M. C. (2006). Narratives and cancer communication. Journal of Communication, 56, 163-183. 
https://doi.org/10.1111/j.1460-2466.2006.00288.x

Herman, D. (2009). Basic Elements of Narrative. UK: John Wiley \& Sons Ltd, publications. https://doi.org/10.1002/9781444305920

Hyw゙arinen, M., Hyden, L.-C., Saarenheimo, M., \& Tamboukou, M. (2010). Beyond Narrative Coherence: Studies in Narrative. Amsterdam \& Philadelphia: John Benjamins Publishing Company. https://doi.org/10.1075/sin.11

Johnstone, B. (2001). Discourse analysis and narrative. In D. Schiffrin, D. Tannen \& H. Hamilton (Eds.), The Handbook of Discourse Analysis (pp. 635-650). Oxford: Blackwell Publishers.

Labov, W. (1972). Language in the Inner City. Philadelphia: University of Pennsylvania Press.

Labov, W. (1981). Speech actions and reactions in personal narrative. In D. Tannen (Ed.), Analyzing Discourses Text and Talk (pp. 217-247). Washington D.C: Georgetown University Press.

Labov, W. (1997). Some further steps in narrative analysis. Oral versions of personal experience. Three Decades of Narrative Analysis. Special Issue of Journal of Narrative and Life History, 7(1-4), 395-415. https://doi.org/10.1075/jnlh.7.49som

Labov, W. (2006). Narrative pre-construction. Narrative Inquiry, 16(1), 37-45. https://doi.org/10.1075/ni.16.1.07lab

Labov, W., \& Waletzky, J. (1967). Oral versions of personal experience. In J. Helm (Ed.), Essays on the Verbal and Visual Arts (pp. 12-44). Seattle: University of Washington Press.

Moore, E. (2006). 'You Tell All the Stories': Using narrative to explore hierarchy within a community of practice. Journal of Sociolinguistics, 10(5), 611-640. https://doi.org/10.1111/j.1467-9841.2006.00298.x

Moyer-Gusé, E. (2008). Toward a theory of entertainment persuasion: Explaining the persuasive effects of entertainment-education messages. Communication Theory, 18(3), 404-425. https://doi.org/10.1111/j.1468-2885.2008.00328.x

Nadeem, N. (2015). Autobiographical narrative: An exploration of identity construction processes in relation to gender and race. Narrative Inquiry, 25(2), 224-241. https://doi.org/10.1075/ni.25.2.02nad

Nadeem, N. (2019). Exploring rhetorical devices as multi-modal conceptual blends in a TED Talk. Journal of Applied Languages and Linguistics, 3(1), 97-128.

Nadeem. N. (2020). Stories that are worth spreading: A communicative model of TED talk narratives. Narrative Inquiry. https://doi.org/10.1075/ni.19037.nad

Ochs, E., \& Capps, L. (1996). Narrating the self. Annual Review of Anthropology, 25, 19-43. https://doi.org/10.1146/annurev.anthro.25.1.19

Ochs, E., \& Capps, L. (2001). Living Narrative: Creating Lives in Everyday Storytelling. Cambridge, MA: Harvard University Press.

Ozylldırım, I. (2009). Narrative analysis: An analysis of Oral and Written Strategies in PENs. Journal of Pragmatics, 41, 1209-1222. https://doi.org/10.1016/j.pragma.2009.01.003

Peterson, C., \& McCabe, A. (1983). Developmental Psycholinguistics. New York: Plenum Press. https://doi.org/10.1007/978-1-4757-0608-6

Pilkington, O. (2017). Structural complexity of popular science narratives of discovery as an indicator of reader-awareness: A Labovian approach. Linguistics and Philosophical Investigations, 16, 7-28. https://doi.org/10.22381/LPI1620171

Polanyi, L. (1982). Literary Complexity in Everyday Storytelling. In D. Tannen (Ed.), Spoken and Written language: Exploring Orality and Literacy (pp. 155-170). Norwood, NJ: Ablex.

Polanyi, L. (1985). Conversational Storytelling. In T. van Dijk (Ed.), Handbook of Discourse Analysis 3: Discourse and Dialogue (pp. 183-201). London: Academic.

Prophet's hadith. (number 11, 2021). Retrieved October 23, 2021, from http://islamicshahada.blogspot.com/2007/02/story-of-three-men.html

Rahman, F. (1983). Some Key Ethical Concepts of the Qur'ān. The Journal of Religious Ethics, 11(2), 170-185.

Richardson, L. (1990). Narrative and sociology. Journal of Contemporary Ethnography, 19, 116-135. https://doi.org/10.1177/089124190019001006 
Schegloff, E. (1997). Narrative Analysis Thirty Years Later. Journal of Narrative and Life History, 7(1-4), 97-106. https://doi.org/10.1075/jnlh.7.11nar

Schiffrin, D. (1996). Narrative as Self-Portrait: Sociolinguistic Constructions of Identity. Language in Society, 25(2), 167-203. https://doi.org/10.1017/S0047404500020601

Schiffrin, D. (2009). Crossing Boundaries: The Nexus of Time, Space, Person, and Place in narrative. Language in Society, 38, 421-445. https://doi.org/10.1017/S0047404509990212

Schreiner, C., Appel, M., Isberner, M.-B., \& Richter, T. (2018). Argument Strength and the Persuasiveness of Stories. Discourse Processes, 55(4), 371-386, https://doi.org/10.1080/0163853X.2016.1257406

Shen, F. Y., Sheer, V. C., \& Li, R. B. (2015). Impact of Narratives on Persuasion in Health Communication: A meta-analysis. Journal of Advertising, 44(2), 105-113. https://doi.org/10.1080/00913367.2015.1018467

Shiro, M. (2003). Genre and Evaluation in Narrative Development. Journal of Child Language, 30, 165-195. https://doi.org/10.1017/S0305000902005500

Slater, M. (2002). Entertainment education and the persuasive impact of narratives. In M. C. Green, J. J. Strange \& T. C. Brock (Eds.), Narrative Impact: Social and Cognitive Foundations (pp. 157-181). Mahwah, NJ: Lawrence Erlbaum.

Slater, M., \& Rouner, D. (2002). Entertainment-Education and Elaboration Likelihood: Understanding the Processing of Narrative Persuasion. Communication Theory, 12, 173-191. https://doi.org/10.1111/j.1468-2885.2002.tb00265.x

Speight, M. (2000). Narrative Structures in the Hadīth. Journal of Near Eastern Studies, 59(4), 265-271. https://doi.org/10.1086/468861

Tannen, D. (1980). A comparative analysis of oral narrative strategies: Athenian Greek and American English. In W. Chafe (Ed.), The Pear Stories (pp. 51-87). Norwood, NJ: Ablex.

Tannen, D. (1982). Oral and literate strategies in spoken and written narratives. Language, 58, 1-21. https://doi.org/10.2307/413530

Tannen, D. (1989). Talking Voices: Repetition, Dialogue, and Imagery in Conversational Discourse. Cambridge, England: Cambridge University Press.

Tannen, D. (2008). We're never been close, we're very different: Three narrative types in sister discourse. Narrative Inquiry, 18, 206-229. https://doi.org/10.1075/ni.18.2.03tan

Tsitsipis, L. (1988). Language shift and narrative performance: On the structure and function of Arvanítika narratives. Language in Society, 17(1), 61-86. https://doi.org/10.1017/S0047404500012598

Watson, K. (1973). A rhetorical and sociolinguistic model for the analysis of narrative. American Anthropologist, New Series, 75(1), 243-264. https://doi.org/10.1525/aa.1973.75.1.02a00150

\section{Copyrights}

Copyright for this article is retained by the author, with first publication rights granted to the journal.

This is an open-access article distributed under the terms and conditions of the Creative Commons Attribution license (http://creativecommons.org/licenses/by/4.0/). 